\title{
OBRAZ SZKOLNEJ CODZIENNOŚCI NAUCZYCIELEK EDUKACJI WCZESNOSZKOLNEJ
}

\begin{abstract}
Streszczenie: W artykule przedstawiono szkolną codzienność nauczycielek edukacji wczesnoszkolnej z ich własnej perspektywy. W tym celu przeprowadzono swobodne wywiady z elementami narracji, zaś analizy i interpretacje uzyskanych danych dokonano zgodnie z paradygmatem interpretatywnym. Badane nauczycielki pomimo wyrażanego $\mathrm{w}$ swoich wypowiedziach niezadowolenia $\mathrm{z}$ odczuwanego przez nie braku docenienia (zarówno społecznego, jak i finansowego) podkreślają znaczenie korzyści z dokonanego wyboru swojej drogi zawodowej. Obcowanie z dziećmi, towarzyszenie im w ich rozwoju, wspieranie i uczenie ich stanowi najważniejsze źródło zadowolenia z wykonywanej pracy. To balansowanie pomiędzy słabym wynagrodzeniem, przerostem biurokracji, niejasnością oczekiwań społecznych a zachwytem nad dzieckiem, czerpaniem satysfakcji z możliwości własnego rozwoju oraz nieszablonowości buduje codzienność nauczycielek edukacji wczesnoszkolnej.
\end{abstract}

Słowa kluczowe: nauczyciel; codzienność; satysfakcja z pracy.

\section{Wprowadzenie}

Codzienność jest wieloaspektowa, nie sposób wyznaczyć jej granic, zawsze jest uwarunkowana historycznie i społecznie, wszelkie elementy ją budujące należą do naturalnego środowiska życia jednostki w społeczeństwie (Kędzierzawski 2009, s. 15-20). Termin „codzienność” w literaturze znaczeniowo ujmowany jest również jako świat życia lub świat przeżywany, który według Ferdynanda Fellmana (1993, s. 52) jest jedynym światem naprawdę doświadczanym. Interesującą definicję codzienności proponuje Piotr Sztompka (2008, s. 24-25), który wskazuje na osiem cech ją charakteryzujących: życie z innymi, powtarzalność zdarzeń, formy rytualne, angażowanie cielesności, lokalizacje w przestrzeni, ramy czasowe, automatyzm oraz

* Dr Ewa Sosnowska-Bielicz, Uniwersytet Marii Curie-Skłodowskiej w Lublinie, Wydział Pedagogiki i Psychologii; e-mail: e.sosnowska-bielicz@poczta.umcs.lublin.pl. 
spontaniczność. W świetle jego rozważań, jak i wielu innych badaczy przedmiotu, najważniejszą właściwością codzienności, lub inaczej mówiąc - świata prezentującego się świadomości w naturalnej postaci, jest oczywistość, która sprawia, że „jest ona przyjmowana bez zastrzeżeń”, co w konsekwencji powoduje, że ujmowana jest jako rzeczywistość sama w sobie (Berger, Lukmann 2010, s. 51).

Z kolei Sławomir Krzychała rozpatruje codzienność, w tym codzienność szkolną, jako „mozaikę zależności, wielorakiego zaangażowania, płynnych ról, oczekiwań, uwarunkowań i aktywności, które łącznie składają się na doświadczenie życia (codziennego)" (2007, s. 35). Z jednej strony tworzą ją proste, zwyczajne czynności, niewymagające zbytniego angażowania się, a $z$ drugiej strony jawi się ona jako „arena zmagań, trudu radzenia sobie w zmieniającej się rzeczywistości pełnej zależności i zmagań” (Krzychała 2007, s. 35), co nasuwa refleksję, że zarazem jest ona i nie jest oczywistością.

Jeżeli za Janem Szczepańskim (1978, s. 99) przyjmiemy tezę, że codzienność to chaos drobnych, schematycznych, powtarzających się operacji, stanowiących nieodłączny element życia człowieka, a jednocześnie przestrzeń życia, której doświadcza każdy człowiek, oraz za Barbarą Smolińską-Theiss (1993, s. 119) - że jest ona przestrzenią społeczną, „w której przebywa i porusza się jednostka”, to codzienność nauczyciela edukacji wczesnoszkolnej stanowiłoby wszystko to, co buduje jego własne postrzeganie własnego miejsca w pracy. Składa się na nią zarówno fizyczne miejsce pracy, jak i to, co stanowi przeżycie tego miejsca, postrzeganie samego siebie i patrzenie na siebie w „lustrze” innych.

Artykuł jest efektem spotkań z nauczycielkami edukacji wczesnoszkolnej, podczas których opowiadały one o swojej pracy zawodowej. Przedstawiane historie stały się inspiracją do napisania artykułu będącego ilustracją codzienności nauczycielek widzianej z ich własnej perspektywy.

\section{Metoda}

Celem prezentowanych rozważań było poznanie i próba zrozumienia interpretacji życia codziennego nauczycielek edukacji wczesnoszkolnej: przyjrzenie się badanym z ich perspektywy (jak one postrzegają swój zawód, jak go oceniają, co w nim lubią, a co im przeszkadza, co sprawia, że nadal pracują w zawodzie i chcą wykonywać swoją pracę, co je motywuje do działania, a co zniechęca). Przyjęty cel badań stanowił główną przesłankę do wyboru badań jakościowych, będących podstawą do metodologii badań własnych. Podejście jakościowe pozwala bowiem na poznanie rzeczywistości badanego z jego perspektywy (Pilch, Bauman 2001, s. 267-284). Do analizy i interpretacji uzyskanych danych przyjęto paradygmat interpretatywny, który umożliwia „interpretowanie zdarzeń w kategoriach znaczeń, jakie przypisują im ludzie" (Denzin, Lincoln 2000, s. 3). W tym paradygmacie rzeczywistość jest konstruowana w toku interakcji przez aktorów (badacza i badanego). Postrzegana jest ona w kontekście nadawania znaczeń, co wymaga rozumienia przeżyć i refleksji 
uczestników tego świata (Konecki 200o, s. 16-18; Urbaniak-Zając 2013, s. 44). Rzeczywistość społeczna jest zaś intersubiektywnie postrzegana i tworzona przez uczestników, czyli ludzi żyjących w świecie społecznym. Mówiąc inaczej, świat cały czas tworzony jest przez ludzi, również przez badaczy, których rolą jest ukazanie owego świata w „akcie tworzenia”. Badacz interpretuje i ukazuje świat, który jego uczestnicy postrzegają jako oczywisty, w ten sposób pokazuje i tłumaczy pewne zjawiska społeczne (Urbaniak-Zając 2013, s. 44-45; Konecki 200o, s. 19-23).

Dla paradygmatu interpretatywnego charakterystyczne są: „luźne wywiady, analiza przypadków oraz obserwacja uczestnicząca” (Krzemiński 1986, s. 92). Konsekwencją takiego podejścia było wybranie wywiadu swobodnego z elementami narracji jako metody badawczej. Pozwoliło to prowadzącemu wywiad na dużą swobodę w aranżowaniu i formułowaniu pytań wskazujących ogólny kierunek rozmowy czy zwróceniu szczególnej uwagi na poruszane przez badanego nowe wątki związane z danym tematem (Kostera 2003, s. 121-122; Kos 2013, s. 91-98). Rolą prowadzącego wywiad było zadawania takich pytań, które skłaniały do dzielenia się posiadaną wiedzą (Babbie 2004, s. 326-327). Zasadą postępowania badawczego była otwartość, innymi słowy, rezygnacja z wszelkiej standaryzacji zbieranego materiału badawczego. Lista pytań była otwarta przez cały czas badania, a wprowadzanie kolejnych, nieprzewidzianych wcześniej pytań było jak najbardziej możliwe (Urbaniak-Zając, Piekarski 2001, s. 22-23). W trakcie procesu badawczego opierano się na założeniach teorii ugruntowanej i jej nurtu konstruktywistycznego, której źródłem jest podejście interpretatywne (Charmaz 2009).

Celem badania było poznanie codzienności zawodowej nauczycielek edukacji wczesnoszkolnej. Aby zmierzyć się z tym zagadnieniem, przeprowadzono wywiady z 14 nauczycielkami na tym poziomie kształcenia. Wywiady prowadzono indywidualnie, najczęściej w miejscu pracy nauczycielek, a wypowiedzi były nagrywane na dyktafon. Starano się zastosować strategię maksymalnego porównania w grupie badawczej, dlatego znalazły się w niej nauczycielki (tylko nauczycielki) o różnym stażu pracy: od roku do 37 lat. Wywiady trwały od 50 do 90 minut, przeprowadzane były w województwie lubelskim od października 2017 do listopada 2018 roku. W niniejszym artykule nie posługiwano się imionami badanych, wywiadom przypisano w sposób losowy numery od N1 do N14.

Specyfika badanej grupy społecznej, jak również przyjęty paradygmat implikują nieprobabilistyczny dobór osób badanych z zastosowaniem metody kuli śnieżnej. Określenie kula śnieżna odnosi się do procesu akumulacji, ponieważ każda badana osoba podaje kolejne osoby z badanej grupy społecznej (Babbie 2004, s. 205). Pamiętając o celu badania i mając na uwadze jakość przeprowadzanych badań, zaplanowano przeprowadzać wywiady aż do osiągnięcia tzw. punktu nasycenia, czyli do momentu, kiedy kolejne wywiady nie dostarczają już nowej wiedzy o przedmiocie badań. W odniesieniu do wszystkich wywiadów dokonano ich dosłownej i prostej transkrypcji. W zapisie stosowano znaki interpunkcyjne (zastosowano interpunkcję zgodną z gramatyką języka polskiego), a także 
kodowano niewerbalne zachowania (np. śmiech, dłuższe zastanowienia, przerwy w wypowiedzi) (Urbaniak-Zając 2016, s. 87). Następnie materiały empiryczne w postaci transkrypcji wywiadów $\mathrm{z}$ nauczycielkami poddano analizom i interpretacji (Urbaniak-Zając 2016, s. 87-98).

\section{Wyniki i dyskusja nad nimi}

Nauczycielki proszone były o opowiedzenie o sobie z perspektywy pracy zawodowej. Wywiad rozpoczynał się ogólnym pytaniem: "Jak to się stało, że została Pani nauczycielką edukacji wczesnoszkolnej?”. Ponieważ celem badań było poznanie subiektywnej wizji codzienności szkolnej nauczycielek, badacz podążał za opowiadaną historią, w zależności od jej treści niekiedy pojawiały się pytania bardziej szczegółowe, tj: „Czy lubi Pani swoją pracę?”, „Czy jest Pani zadowolona ze swojej pracy?”, a niekiedy pytania projekcyjne: „Czy gdyby mogła Pani wybierać jeszcze raz swoją drogę zawodową, zdecydowałaby się Pani na zawód nauczyciela?". Nauczycielki chętnie i pewnie odpowiadały na pytania, uzasadniając swoje stanowiska.

Badane nauczycielki deklarowały zadowolenie $\mathrm{z}$ tego, że pracują w swoim zawodzie, większość z nich chciała wykonywać taką właśnie pracę, czego ilustracją może być następująca wypowiedź: „[...] Nie myślałam o innej drodze, innej karierze, chociaż robiłam różne rzeczy" (N4). Ta wypowiedź odzwierciedla stanowisko większości nauczycielek, chociaż pojawiały się pojedyncze wypowiedzi o możliwości zmiany zawodu w przyszłości na pokrewny, ale mniej obciążający i mniej wyczerpujący.

Każdy zawód, jak każde wykonywane przez człowieka działanie, niesie ze sobą zarówno pozytywy, jak i negatywy. Trudno byłoby znaleźć zawód, który miałby tylko dobre strony. Nauczycielki proszone były o nakreślenie zalet i wad swojej pracy poprzez opowiedzenie, co w niej lubią, a czego nie. Na podstawie analizowanych wywiadów wyróżnione zostały dwie główne kategorie nastawienia do pracy nauczycielek edukacji wczesnoszkolnej, a w każdej z nich kilka podkategorii, które przedstawiono w tabeli 1.

Z analizy narracji wyłonić można cztery główne zarzuty nauczycielek odnoszące się do wykonywanego przez nie zawodu: przeładowanie biurokracją, sam system szkolny, niskie wynagrodzenie oraz coraz mniejsze uznanie społeczne lub jego brak (Mroczka 2011). Największy sprzeciw budzi przerost biurokracji, który postrzegany jest jako niepotrzebny i zabierający czas nauczycielowi. Zjawisko to widziane jest jako coś zbędnego, czasami wręcz niezasadnego i przede wszystkim zajmującego nauczycielom dużo czasu, który mogliby spożytkować na przygotowanie się do zajęć i pracę z dziećmi. 
Tabela 1. Kategorie nastawienia do pracy nauczyciela edukacji wczesnoszkolnej

\begin{tabular}{|l|l|}
\hline $\begin{array}{c}\text { Zalety pracy w zawodzie pracy nauczy- } \\
\text { ciela edukacji wczesnoszkolnej }\end{array}$ & $\begin{array}{c}\text { Wady pracy w zawodzie pracy nauczy- } \\
\text { ciela edukacji wczesnoszkolnej }\end{array}$ \\
\hline $\begin{array}{l}\text { Dzieci - kontakt z dziećmi, praca } \\
\text { z dziećmi; } \\
\text { twórczy charakter pracy i możliwość reali- } \\
\text { zowania swoich pasji; } \\
\text { uznanie ze strony dzieci i rodziców. }\end{array}$ & $\begin{array}{l}\text { Nadmiar biurokracji/buchalteria; } \\
\text { nieadekwatność gratyfikacji finansowej/ } \\
\text { słabe wynagrodzenie; } \\
\text { tradycyjny system edukacji; } \\
\text { brak uznania ze strony innych podmiotów } \\
\text { życia szkoły. }\end{array}$ \\
\hline
\end{tabular}

Źródło: opracowanie własne.

„No powiem, teraz buchalterii tej bardzo. To chyba nikt nie lubi. Tak. Tak, często tworzymy dokumenty, które naprawdę, tak z perspektywy chyba nikomu nie służą, tak do końca" (N6).

„Tak. Biurokracja i papierologia. Że trzeba zamiast poświęcić czas tak naprawdę tylko dziecku i lekcji, to ty musisz te plany, rozkłady, tematy. Ja wiem, że to jest potrzebne, ale żeby to troszkę tak ukrócić, żeby to troszkę tak... Właśnie te tabelki. Nigdy nienawidziłam właśnie tych tabelek. My jesteśmy dla dzieci, a nie dla papierologii, dla pani minister" (N12).

„Ja papirologię mam niestety... Nie lubię papirologii. Jest to dla mnie duża strata czasu. Wolałabym pracować z dziećmi. Malować, pisać, liczyć, czytać, tylko nie uzupełniać tej papirologii, bo w tym jestem najsłabsza" (N14).

Nauczycielki uważają za szczególnie zbędne wielokrotne powtarzanie zapisów w różnych aspektach i formie. Wprowadzenie dzienników elektronicznych miało nieco zmniejszyć ilość dokumentacji, ale nadal są szkoły, w których praca nauczyciela jest podwójna - elektroniczna i papierkowa. Na aspekt biurokratyzacji zawodu nauczyciela zwróciła również uwagę Małgorzata Zalewska-Bujak (2017, s. 270-275), która analizując i interpretując wypowiedzi nauczycieli, pisze o biurokracji jako o „polu przemocy symbolicznej”. Dla nauczycieli ten element ich pracy jest postrzegany jako odciągający ich od meritum ich zawodu, od pracy z uczniami.

Innym mankamentem w zawodzie nauczyciela edukacji wczesnoszkolnej jest obecny system edukacji. Wyłaniająca się z wypowiedzi nauczycielek codzienność edukacji wczesnoszkolnej pełna jest pośpiechu, brakuje w niej czasu na ciekawe i atrakcyjne zajęcia dla dzieci. Odgórnie przyjęte wymagania dotyczące realizowania podstawy programowej niejednokrotnie uniemożliwiają nauczycielom wprowadzenie innowacji czy chociażby urozmaicenia w edukacji małego dziecka.

„Boję się tego, bo ja czasami mówię: kurcze, ja bym zrobiła to, tamto. Nawet mam takie materiały, które kiedyś na studiach robiłyśmy z koleżanką, to bym to wykorzystała. Ale myślę sobie: kurcze, no to zrobię, to mi się przedłuży, 
a lekcja 45 minut i tak mi leci szybko lekcja, że po prostu szok. Strasznie szybko. Strasznie szybko. Kiedy mam jakiś ciekawy temat, mam coś narzucone z góry i to już mnie tak ogranicza i nie mogę gdzieś tam np. zrobić czy pracy, czy pracy plastycznej, bo jednak tę plastykę to już zrobiłam w tym tygodniu, a później mi się nie zliczy. I ja się teraz tym martwię. Myślę: Boże, raz zrobiłam trzy przyrody jednego dnia, no to później już będę miała jakiś deficyt czy coś, czy jakieś... I to mnie gdzieś tam też... To jest taka rzecz. Że ktoś mnie sprawdza, ktoś mnie może skontrolować. To na pewno. To mnie przeraża [śmiech]" (N9).

„Jakby ja nie lubię systemu szkolnego [...] Ja w przedszkolu mogłam sobie jakby pozwolić na robienie fajnych rzeczy z dziećmi, gdzie ja czułam, że one mają sens, wiedziałam, że są atrakcyjne dla dzieci i że są dla nich ważne i pożyteczne. Tak, miałam po prostu czas. Miałam po prostu na to czas. W szkole trochę tego czasu nie mam [...] no ja nie lubię nauczania tradycyjnego. I to to chyba mnie tak niszczy. A w szkole jednak tego się wymaga" (N8).

Kolejnym minusem w pracy nauczyciela małego dziecka, wyłaniającym się z narracji badanych nauczycielek, jest niedocenianie ich roli przez społeczeństwo. To poczucie braku uznania względem nauczycieli charakteryzuje zarówno rodziców, jak i przełożonych, oraz ogólnie - opinię społeczną. Nauczycielki zauważają negatywny wpływ mediów na ich wizerunek i koncentrowanie się tylko na złych przykładach, wpadkach i niepowodzeniach nauczycieli. Wskazywana jest również niewiedza rodziców o realiach pracy nauczyciela, jako jedno ze źródeł braku docenienia, jak również tendencja do przerzucania odpowiedzialności za efekty nauki i kształcenie dzieci tylko na nauczyciela. W opinii badanych rodzice postrzegają szkołę i nauczycieli z perspektywy funkcjonowania własnego dziecka i jego sukcesów i porażek - rodzic nie patrzy na nauczyciela przez pryzmat całości jego działań, zaangażowania i zadań, które wykonuje często poza godzinami swojej pracy.

„A mało jest takich pozytywnych informacji, że nauczyciele pracują, że poświęcają swój czas na prywatne, na... na przykład, chociażby taką wycieczkę. Mamy w programie trzy godziny dydaktyczne z uczniami, a jedziemy na 12 godzin na wycieczkę, nikt nam nie płaci za godziny nadliczbowe przepracowane, tak. Także no myślę, że rodzice może nie mają świadomości tych naszych starań w większości i bardzo indywidualnie to odbie... odbierają naszą pracę, z perspektywy tego, jak ich dziecko egzystuje w szkole. Jeśli dziecko nie ma problemów, no to uważają, że nauczyciel pracuje dobrze, w szkole wszystko jest... się dobrze dzieje. Gorzej jest, kiedy są jakieś sytuacje trudne, to wtedy często rodzice całą odpowiedzialność przerzucają na nauczyciela" (N5).

Nauczycielki podkreślają rolę i znaczenie postępowania rodziców jako wzorów dla swoich dzieci. Postawa roszczeniowa i braki w kulturze osobistej są kolejnymi 
czynnikami negatywnie rzutującymi na relacje rodzic-nauczyciel. Niedostrzeganie przez rodziców niewłaściwego zachowania dzieci i brak oczekiwanej przez nauczycielki reakcji rodziców na to zachowanie oraz ogólna niechęć do nauczyciela są zauważalne i odbierane przez nauczycielki jako trudność i ujemna strona ich zawodu. W narracjach słychać również brak uznania dla działań nauczycielek ze strony dyrekcji. Niektóre z nich wprost mówią o braku pochwał i wyrazu zadowolenia ze strony przełożonych i widzą to jako słabą stronę pracy nauczyciela.

„O: Czego nie lubię? Nie lubię w swojej pracy tego, że my nie jesteśmy doceniani za to, nawet takim słowem, po... fajnie to zrobiłeś i tyle, tylko jest krytykowanie.

B: A z czyjej strony?

O: Szefostwa. Znaczy nie, nie to, że nawet, co robię źle, tylko na zasadzie, że jeśli coś robię fajnego, to nie ma podkreślenia, że fajnie, że zrobione, cokolwiek i cały czas narzucanie, ustawianie coraz większej ilości zadań” (N7).

Aspekt finansowy pojawiał się dość często w narracjach badanych nauczycielek. Mówiąc o nim, zwykle wyrażały niezadowolenie - wskazywany był jako ważny powód ewentualnej zmiany zawodu. W odczuciu badanych nauczyciel nie jest odpowiednio wynagradzany, a nie dość wysoka gratyfikacja finansowa budzi zawód, uczucie niedocenienia, niekiedy refleksję nad wartością i znaczeniem pracy nauczyciela we współczesnym świecie. W narracjach wprost pojawiają się informacje, że bez wsparcia finansowego rodziny wynagrodzenie nauczycielek byłoby niewystarczające do zapewnienia bytu.

„[...] gdybym może zwracała uwagę na finanse, na pieniądze, to to by było może takie. Bo faktycznie, jest to zawód trochę za mało wynagradzany, niskie te gratyfikacje, mimo że jestem nauczycielem dyplomowanym, mimo że mam studia podyplomowe, szereg tych kursów, opieki, tamto, no... [...] Ja generalnie nie przywiązuję wagi do pieniędzy, ale jak już powstała rodzina, swoje gniazdo, gdzie już trzeba było pulę męża, pulę swoją i to podzielić, i jakoś, to okazuje się, że nie są to wielkie pieniądze" (N6).

„Ja wiem, że ja mogę polegać na tych osobach, które są razem ze mną, mieszkają. Które mnie w każdej sytuacji wesprą. I w sytuacji szkolnej. A o sytuację domową się nie muszę martwić. Był taki czas, że mój mąż wspierał mnie i finansowo również, jeśli chodzi o szkołę, bo szkoła pieniędzy nie miała. Więc on finansował wiele, wiele rzeczy, które ja miałam [zastanowienie] w planach, pomysły" $\left(\mathrm{N}_{4}\right)$.

Aspekt finansowy pojawiał się również w innych kontekstach - gdy poruszane były zagadnienia motywacji do pracy czy satysfakcji z wykonywanego zawodu. 
Jeśli temat finansów został poruszony przez nauczycielki, to zawsze występował w kontekście niezadowolenia z poziomu gratyfikacji finansowej.

„Hmmm... co mnie do pracy motywuje [specyficzny dla badanej wyraz dźwiękonaśladowczy - cyt], noo... na pewno nie dodatek motywacyjny, śmieszny [...], to nie ma tak, że ktoś mnie musi motywować takim dodatkiem motywacyjnym śmiesznym i na pewno oczywiście chciałoby się zarabiać więcej, ale zarabiamy tyle, ile zarabiamy" $\left(\mathrm{N}_{3}\right)$.

„Bo nie jesteśmy opłacani tak, jak powinniśmy być opłacani. Każdy... wszyscy myślą, że tak, że ma 18, przychodzi i nic nie robi, a to wcale tak nie jest. No bo obciążenie psychiczne jest bardzo duże, no bo ponosi się odpowiedzialność za tego młodego człowieka, którego się dostaje w swoje ręce - że tak to określę - i którego trzeba nauczyć, którego, no, trzeba ukształtować, tak myślę... No, powiedzieć mu, co jest dobre, a co nie jest dobre... przekazać mu jakieś normy, w których on potem wzrasta" $\left(\mathrm{N}_{1}\right)$.

Przechodząc do omawiania zalet i źródeł zadowolenia z pracy zawodowej, należy zwrócić uwagę, że niewątpliwie najistotniejszą kwestią w pracy nauczycielek edukacji wczesnoszkolnej jest kontakt z dziećmi. To jest w ich opinii największą zaletą i stanowi główny motywator do pracy. Ważne jest to, co one wnoszą do szkolnej codzienności. Nauczycielki edukacji wczesnoszkolnej lubią w swojej profesji również kreatywność i twórcze działania, będące dla nich motorem napędzającym i najprzyjemniejszym aspektem ich pracy.

„[...] dzieci lubię. Dzieci lubię. Nie no, generalnie lubię z nimi pracować.. Ale bardzo lubię pracować z dziećmi, bardzo lubię szykować zajęcia właśnie takie... Bardzo lubię grać $\mathrm{z}$ dziećmi w gry. Często szykuję im takie zajęcia z grami, tak? [krótka przerwa] Więc jakby ja tak sobie, tak myślę, co mnie trzyma, to naprawdę jakby to, że no lubię, lubię po prostu pracować z dziećmi [...] lubię bardzo robić z nimi jakieś ciekawe właśnie zajęcia. Mieć czas na fajną pracę" (N8).

Innymi cechami, które cenią sobie nauczycielki edukacji wczesnoszkolnej w swojej pracy, są: brak rutyny, niepowtarzalność sytuacji, możliwość realizacji siebie, odgrywania różnych ról, stawiania sobie i dzieciom wyzwań. Należy nadmienić, że niejednokrotnie w narracjach wymieniana była więcej niż jedna rzecz ze wskazanych powyżej.

„To, że każdego dnia mogę się wcielić w inną rolę. Bo jak mówimy o zawodzie lekarza, to mogę być lekarką. Dzisiaj mówiliśmy... wczoraj było o przetworach, to po prostu bawiłam się z nimi z tymi przetworami. Dzisiaj do nich weszłam, bo mówiliśmy o koszmarach sennych. I dzisiaj do nich weszłam, 
mówię: Boże, dzieci, wiecie co? Mi się tak coś przyśniło w nocy, musicie mi coś pomóc. I oni się tak na mnie patrzą. [...] I to właśnie jest to, że mogę się wcielić i za każdym razem mogę przeżywać coś innego i opowiadać im coś innego, i wcielać się w każdą rolę, że nie ma monotonii w moim zawodzie. Każdy dzień jest inny, każdego dnia spotykam się z innymi emocjami swoimi, innymi ich emocjami, musimy sobie radzić. Nie ma siedzenia, liczenia pieniążków jak w banku albo gdzie indziej" (N12).

„Mi się podoba też to, że ja się dokształcam. Ja mimo to, że III klasę mam drugi rok czy tam trzeci, za każdym razem mamy inne treści i ja za każdym razem coś innego odkrywam. Ja się też razem z nimi uczę. I ja sama lubię się dokształcać, lubię coś wiedzieć, lubię ich czymś zaskoczyć, ale lubię też być zaskakiwana. Lubię, jak oni mnie też czymś zaskoczą, jak z czymś do mnie przyjdą. Lubię też poszukiwać i dociekać, dlaczego tak jest, a nie inaczej? Jak ja mogę mu pomóc? To jest też takie fajne, że to jest takie rozwijające i mnie, i ich. To mi się bardzo podoba" (N12).

„Chyba kontakt z dziećmi. Kontakt z dziećmi. To, że każdy dzień, że właściwie, niby człowiek przewiduje, pisze sobie... tak, mimo to, że ja wiem, co na zajęciach zrobię, jakby przewiduję, jakie cele chcę osiągnąć, na co zwracam uwagę, co chcę po tych zajęciach, żeby dzieci wyniosły, to chyba taka nieprzewidywalność właściwie każdego dnia. Bo to jest żywy organizm właściwie. Niby wiem, no ale to jest też różnie. I to chyba mnie tak ciekawi, taka... I taka trochę moja wolność, powiem. I to mi się podoba, że ja właściwie wchodzę, jakby bawię się w tę szkołę i czy ja powiem tak, czy ja wezmę lalkę, czy ja coś, podskoczę, to już jest moja inwencja. I to mi się podoba. Taka trochę, taka swoboda. Nie mam takich ram. Ramy to te metodyczne trochę, to, a moje ramy, gdzie, no, muszę tam trochę trzymać się tego, prawda, jakaś metodyka obowiązuje, ale samo takie aktorstwo, powiem, o tu, w klasie, to już jest moja inwencja. O. I tak. [...] I to mnie chyba też pociąga. Tak, te dzieci i cieszy mnie to, jak mnie słuchają, jak tak patrzą, ja się wygłupiam...” (N6).

Odnosząc te wypowiedzi do omawianego zagadnienia, można za Zygmuntem Baumanem (2009, s. 78) zauważyć, że „niecodzienność jest dziś codziennością”. Dla badanych nauczycielek brak rutyny, niepowtarzalność sytuacji, zaskakujące i nieprzewidywalne sytuacje stanowią ich codzienność, a jednocześnie są jej atutem. Na to zjawisko zwraca uwagę również Krajewski (2009, s. 197), podkreślając, iż nieodłącznym aspektem codzienności, obok fundamentalnej powtarzalności, jest improwizacja i prowizorka.

W narracjach nauczycielek edukacji wczesnoszkolnej wyraźnie się zaznacza, że najważniejszym walorem i źródłem zadowolenia z pracy jest dla badanych sama praca i to, co w niej jest dla nich najważniejsze - dzieci. Nauczycielki definiują satysfakcję z pracy poprzez swoje oddziaływanie na uczniów, kontakt z dziećmi i samo przebywanie $\mathrm{z}$ nimi. 
„Każdy dzień daje satysfakcję, dosłownie, bo jeżeli mówią „o, dziś był fajny dzień", albo chodzą zakatarzone, zasmarkane, bo nie chcą stracić ani jednego dnia, ale ten niech żałuje, że go nie było [zdanie wypowiedziane nieco głośniej], ale dzieci też są chore, wiem, że są chore, ale mówią: „niech żałuje, że go nie było", tak" (N3).

„Sama praca z dziećmi mnie motywuje, ...No, ale wie Pani... to jest taka maszyna, nie wiem, sam się człowiek właściwie nakręca dziećmi, dzieci mnie nakręcają. Jeszcze to, jeszcze tamto" (N3).

„Lubię to, co robię. Kocham to, co robię, kocham moje dzieci... iii... wszystkie dzieci ...zawsze mówię, że są to moje dzieci. Tak” (N1).

„To, że się dostaje takie małe dziecko. Przychodzi, nie umie pisać. Wszystko jest dla niego trudne. Siedzieć nie potrafi w ławce tyle, ile siedzieć trzeba. A w III klasie wychodzi [wrażenie podziwu], i ono wie, że jak pani się uśmiechnie, to jest, po minie rozpoznaje, że to jest dobrze. Albo że to już potrafi. Ten rozwój przez trzy lata dostrzegalny, to jest po prostu nagroda za, za wkład włożony" (N14).

„No, satysfakcja, widzi się to, co się wypracuje, wszystkie efekty, każdą literkę, każde dodawanie, postępy tych dzieci... iii... tę pracę rzeczywistą, to serce, które się im okazuje, to wraca..." (N1).

\section{Konkluzje}

Analizując wypowiedzi nauczycielek, można wyobrazić sobie, że ich codzienność to balansowanie między tym, co ich motywuje do pracy, co sprawia, że tę pracę lubią, kochają i jest ona dla nich źródłem satysfakcji, a tym, co je zniechęca, co jest powodem ich niezadowolenia i czynnikiem obniżającym ich motywację do pracy w zawodzie.

Najbardziej motywującym czynnikiem dla badanych edukacji wczesnoszkolnej jest praca $\mathrm{z}$ dziećmi, możliwość towarzyszenia im i wpływania na ich rozwój. Kontakt z dziećmi jest dla nich również źródłem satysfakcji zawodowej. Poza tym ważnym czynnikiem jest możliwość realizowania się poprzez kreatywne i twórcze działania oraz poświęcanie się swoim pasjom. Rudolf Kretschamann (2003, s. 15-21) zwrócił uwagę na aspekt osobistego zaangażowania i subiektywnej wizji szkoły jako czynniki różnicujące poziom zadowolenia z pracy nauczycieli. W jego badaniach największą satysfakcję zawodową wyrażali ci nauczyciele, którzy przy dużym zaangażowaniu w pracę gotowi byli do pewnych ustępstw wobec systemu szkolnictwa (podporządkowania się programowi nauczania, przestrzegania dyscypliny). Najmniej zadowoleni zaś byli ci, którzy krytykowali system szkolnictwa i dostrzegali wyłącznie jego represyjny charakter, oraz ci, którzy przy niewielkim zaangażowaniu usiłowali w pełni sprostać wymaganiom tego systemu, bezkrytycznie podchodząc do rzeczywistości. W odniesieniu do prezentowanych 
wyników warto zauważyć, iż wszystkie badane nauczycielki deklarowały pozytywne nastawienie do swojej pracy, co prawdopodobnie wiązało się z ich dużym zaangażowaniem $\mathrm{w}$ pracę. W przypadku wszystkich badanych wybór zawodu był świadomy i celowy - chciały być nauczycielkami małego dziecka. Taka praca była wyrazem ich marzeń i dążeń. Być może stąd właśnie wynikała ich decyzja pozostania w zawodzie pomimo dostrzegania trudności i wad.

Codzienność nauczycielek edukacji wczesnoszkolnej to przede wszystkim praca z dziećmi, stanowiąca główne źródło zadowolenia i satysfakcji. Pomimo tego, że rutynowe działania, „oczywistość” pracy nauczyciela wypełniona jest aktywnościami skierowanymi na uczniów (źródło ich satysfakcji zawodowej), badane osoby dostrzegają mankamenty i minusy pracy, wpływające znacząco na ich życie zawodowe. Nieustanne współistnienie motywatorów i demotywatorów wypełnia „arenę codzienności” nauczycielek. Jak wady pracy nauczyciela badane kobiety wymieniają: niewystarczające wynagrodzenie, nadmiar biurokracji, brak uznania społecznego. Te czynniki można uznać za niezależne od nauczyciela. Odnosząc je do teorii Edmunda Herzberga (1959, za: Jakimiuk 2017, s. 73), podejmującej zagadnienie satysfakcji zawodowej, są one czynnikami higieny. Wymienione w wynikach badań źródła satysfakcji nauczycielek edukacji wczesnoszkolnej można uznać za motywatory budujące wymiar zadowolenia. W świetle przywołanej teorii można wyjaśnić, iż pozytywne emocje wobec swojej pracy, prezentowane przez nauczycielki, wynikają z zaspokajania potrzeb samorealizacyjnych i rozwojowych, stanowiących wyznacznik pozytywnego nastawienia do pracy.

Dla nauczycielek biorących udział w badaniu także aspekt finansowy jest czynnikiem obniżającym poziom zadowolenia z pracy zawodowej, poza przerostem biurokracji, obniżającym się prestiżem zawodu nauczyciela oraz ograniczoną (przez system kształcenia) autonomią nauczyciela, szczególnie w aspekcie doboru treści i sposobu realizacji lekcji. W deklaracjach badanych kwestie te są jednak równoważone poprzez czynniki niemierzalne, takie jak: przyjemność z pracy z dzieckiem, twórczy charakter pracy czy możliwość wykorzystywanie własnego potencjału, kreatywność i twórczy charakter pracy.

Podsumowując, codzienność nauczycielek edukacji wczesnoszkolnej wypełnia balansowanie pomiędzy kosztami przez nie ponoszonymi a zyskami, jakie każdego dnia przynosi im praca z dziećmi. Być może ten bilans zysków i strat, pomimo odczuwalnych i wskazywanych przez nauczycielki czynników negatywnych, pozwala czerpać z pracy zadowolenie i satysfakcję. Pewnym potwierdzeniem tej tezy może być wypowiedź jednej z badanych nauczycielek: „Mnie jest dobrze tu, gdzie jestem. [...] uważam, że rola nauczyciela właśnie tych maluchów, takiego przewodnika, jest super zajęciem i mnie to sprawia przyjemność" (N4). 


\section{Bibliografia}

Babbie E. (2004). Badania społeczne praktyce. Warszawa: Wydawnictwo Naukowe PWN.

Bauman Z. (2009). Sztuka życia. Kraków: Wydawnictwo Literackie.

Berger P.L., Lukmann T. (2010). Społeczne tworzenie rzeczywistości. Warszawa: Wydawnictwo Naukowe PWN.

Charmaz K. (2009). Teoria ugruntowana. Praktyczny przewodnik po analizie jakościowej. Warszawa: Wydawnictwo Naukowe PWN.

Denzin N.K., Lincoln Y.S. (200o). Metody badań jakościowych. T. 1. Warszawa: Wydawnictwo Naukowe PWN.

Fellman F. (1993). Świat przeżywany $i$ świat duchowy. Fenomenologiczne pojęcie świata a protestancka filozofia kultury. W: Świat przeżywany. Fenomenologia i nauki społeczne. Krasnodębski Z., Nellen K. (red.). Warszawa: Państwowy Instytut Wydawniczy.

Jakimiuk B. (2017). Relacje zawodowe i osiągnięcia osobiste jako czynnik satysfakcji $z$ pracy nauczycieli a ich indywidualne doświadczenia. Lublin: Wydawnictwo KUL.

Kędzierzawski W. (2009). Codzienność jako kategoria antropologiczna w perspektywie historii kultury. Opole: Wydawnictwo Uniwersytetu Opolskiego.

Konecki K. (200o). Studia z metodologii badań jakościowych. Teoria ugruntowana. Warszawa: Wydawnictwo Naukowe PWN.

Konecki K. (2012). Metodologia teorii ugruntowanej - strategia analiz i badań jakościowych. W: Słownik socjologii jakościowej. Konecki K., Chomczyński P. (red.). Warszawa: Difin.

Kos E. (2013). Wywiad narracyjny jako metoda empiryczna. W: Badania jakościowe w pedagogice. Urbaniak-Zając D., Kos E. (red.). Warszawa: Wydawnictwo Naukowe PWN.

Kostera M. (2003). Antropologia organizacji. Warszawa: Wydawnictwo Naukowe PWN.

Krajewski M. (2009). Dzisiaj jak wczoraj, jutro jak dziś. Codzienność, przedmioty i reżimy podtrzymujące. W: Barwy codzienności. Analiza socjologiczna. Bogunia-Borowska M. (red.). Warszawa: Wydawnictwo Naukowe Scholar.

Kretschmann R. (2003). Stres w zawodzie nauczyciela. Gdańsk: GWP.

Krzemiński I. (1986). Symboliczny interakcjonizm i socjologii. Warszawa: Wydawnictwo Naukowe PWN.

Krzychała S. (2007). Projekty życia. Młodzież w perspektywie badań rekonstrukcyjnych. Wrocław: Wydawnictwo DSW

Mroczka E. (2011). Fenomenologia jako metoda postępowania badawczego nad tożsamościa nauczycieli wczesnej edukacji. W: Pedagogika wczesnej edukacji. Dyskursy, problemy, otwarcia. Klus-Stanska D., Bronk D., Molenda A. (red.). Warszawa: Wydawnictwo Akademickie „Żak”. 
Pilch T., Bauman T. (2001). Zasady badań pedagogicznych. Strategie ilościowe i jakościowe. Warszawa: Wydawnictwo Akademickie „Żak”.

Smolińska-Theiss B. (1993). Dzieciństwo w małym mieście. Warszawa: Wydawnictwa Uniwersytetu Warszawskiego.

Szczepański J. (1987). Sprawy ludzkie. Warszawa: Czytelnik.

Sztompka P. (2008). Życie codzienne - temat najnowszej socjologii. W: Socjologia codzienności. Sztompka P., Bogunia-Borowska M. (red.). Kraków: Wydawnictwo Znak.

Urbaniak-Zając D., Piekarski J. (2001). Jakościowe orientacje w badaniach pedagogicznych. Łódź: Wydawnictwo Uniwersytetu Łódzkiego.

Urbaniak-Zając D. (2013). Jakościowe orientacje w badaniach pedagogicznych. W: Badania jakościowe w pedagogice. Urbaniak-Zając D., Kos E. (red.). Warszawa: Wydawnictwo Naukowe PWN, s. 19-90.

Urbaniak-Zając D. (2016). W poszukiwaniu teorii działania profesjonalnego pedagogów. Kraków: Impuls.

Zalewska-Bujak M. (2017). Nauczyciel w polu szkolnym - w świetle teorii Pierre'a Bourdieu i nauczycielskich narracji. Katowice: Wydawnictwo Uniwersytetu Śląskiego.

\title{
AN IMAGE OF THE SCHOOL EVERYDAY LIFE OF EARLY EDUCATION TEACHERS
}

\begin{abstract}
This article is an attempt to present the school everyday life of early childhood teachers from their own perspective. Unstructured interviews with narrative elements were carried out. The analysis and interpretation of the obtained data was carried out in accordance with the interpretative paradigm. The surveyed teachers, despite their dissatisfaction with their lack of appreciation (both social and financial) in their stories, emphasize the importance of the benefits of choosing their professional path. Working with children, accompanying them in their development, supporting and teaching them is the most important source of satisfaction with their work. This balancing between poor pay, excessive bureaucracy, ambiguity of social expectations and admiration for children, gaining satisfaction from the possibilities of their own development and unconventionality build the everyday life of early school teachers.
\end{abstract}

Keywords: teacher; everyday life; job satisfaction. 